\title{
The Importance of Arcuate Foramen, A Variation of the Atlas: A Microsurgical Cadaveric Study and Review of the Literature
}

\section{Atlasın Varyasyonu Arkuat Foramenin Önemi: Bir Mikroșirürjikal Kadavra Çalışması ve Literatürün Gözden Geçirilmesi}

\author{
(1) Neşe Keser ${ }^{1}$, (1) Ulaş Çıkla², (1) Burak Özaydın², (1) Mustafa Başkaya² \\ 1istanbul Fatih Sultan Mehmet Training and Research Hospital, Clinic of Neurological Surgery, İstanbul, Turkey \\ 2University of Wisconsin Faculty of Medicine, Department of Neurological Surgery, Wisconsin, USA
}

\begin{abstract}
Introduction: Arcuate foramen (AF) is an osseous variation located on the vertebral artery (VA) groove (sulcus arteriae vertebralis) at the posterior arch of the atlas. Its prevalence may vary due to regional and ethnic factors. Although it is thought that it causes compression of the structures inside AF and causes vertebrobasilar insufficiency, there are not enough cadaver studies to explain this clinical condition.

Methods: To evaluate the incidence of AF variation and its relationship with VA, 20 sides of 10 randomly selected and silicone injected cadaveric heads were examined by microsurgical method at the University of Wisconsin Neuroanatomy Laboratory.

Results: Complete AF variation in atlas was detected in $30 \%$ of the samples. This variation was unilateral on the right side in two cases and bilateral in one case. The mean dimensions of $\mathrm{AF}$ were $\mathrm{D} 1=6 \mathrm{~mm}$ and $\mathrm{D} 2=5.5 \mathrm{~mm}$ on the right, and $\mathrm{D} 1=7.5$ $\mathrm{mm}$ and D2=6.5 $\mathrm{mm}$ on the left. The mean pre-foraminal, foraminal and post-foraminal diameters of VA were $4 \mathrm{~mm}, 2.5$ $\mathrm{mm}$ and $3 \mathrm{~mm}$, respectively, on the right, and $6 \mathrm{~mm}, 4 \mathrm{~mm}$ and $5 \mathrm{~mm}$, respectively, on the left. In all cases, the suboccipital nerve was accompanying VA in the AF.

Conclusion: Being aware that this variation may have a high incidence may help to determine surgical strategy before craniocervical junction surgery and prevent life-threatening arterial injuries. In addition, although the dimensions of the $\mathrm{AF}$ is adequate for the passage of $\mathrm{VA}$, presence of arterial compression due to other structures passing through the foramen may explain the reason for the relief of most cases with foramen decompression.
\end{abstract}

Keywords: Arcuate foramen, atlas, cadaver study, osseous anomaly, vertebral artery, vertebrobasilar insufficiency

\section{öz}

Amaç: Arkuat foramen (AF) atlasın posterior arkındaki vertebral arter (VA) oluğunda (sulkus arteriae vertebralis) bulunan, prevalansı bölgesel ve etnik faktörler nedeni ile değișebilen osseöz bir varyasyondur. AF'nin içindeki yapılara bası olușturarak vertebrobaziler yetmezlik bulgularına neden olduğu düșünülse de bu kliniği açıklayacak yeterli sayıda kadavra çalışması yoktur.

Yöntemler: AF varyasyonun insidansını ve içinden geçen VA ile olan ilişkisini değerlendirmek için renkli silikon enjekte edilmiş ve rastgele olarak seçilmis 10 kadavranın 20 tarafı Wisconsin Üniversitesi Nöroanatomi Laboratuvarı'nda mikroşirürjikal yöntem ile incelendi.

Bulgular: Örneklerin \%30'unda atlasta komplet tipte AF varyasyonu saptandı. Bu varyasyon iki olguda sağda tek taraflı iken bir olguda bilateraldi. AF'nin ortalama boyutları sağda D1=6 mm, D2 =5,5 mm, solda D1=7,5 mm, D2 $=6,5$ $\mathrm{mm}$, VA'nın ortalama çapı ise foramen öncesi, foramen içi ve foramen sonrası sırası ile sağda $4 \mathrm{~mm}, 2,5 \mathrm{~mm}$ ve $3 \mathrm{~mm}$, solda $6 \mathrm{~mm}, 4 \mathrm{~mm}$ ve $5 \mathrm{~mm}$ idi. Olguların hepsinde suboksipital sinir AF içerisinde VA'ya eşlik ediyordu.

Sonuç: Bu varyasyonun yüksek insidansının olabileceğinin bilinmesi kraniyoservikal bileşke ameliyatlarından önce ameliyat stratejisinin belirlenmesini ve hayati tehlike yaratabilecek arter yaralanmalarının engellenmesini sağlayabilir. Ayrıca, AF boyutlarının VA'nın rahatlıkla geçişine uygun olmasına karșın foramen içinden geçen diğer yapılar nedeni ile arteryel bası olușturduğunun görülmesi foramen dekompresyonu ile olguların çoğunun rahatlama nedenini de açıklayabilir.

Anahtar Kelimeler: Arkuat foramen, atlas, kadavra çalıșması, osseöz anomali, vertebral arter, vertebrobaziler yetmezlik

(c) Copyright 2019 by the Istanbul Training and Research Hospital/istanbul Medical Journal published by Galenos Publishing House. 


\section{Introduction}

Arcuate foramen (AF) is an osseous variation on the vertebral artery groove (sulcus arteriae vertebralis) at the posterior arch of the atlas. The vertebral venous plexus, perivascular sympathetic plexus and suboccipital nerve pass along with the vertebral artery (VA) and it is defined by more than one name in the literature (1,2) (Appendix 1). This foramen, which is normally found in the first cervical vertebrae of primates and other lower vertebrates, has been reported in complete or incomplete types in humans, and its prevalence ranges from $5 \%$ to $68 \%(1-18)$.

Cadaver studies are an important method in elucidating the ethiopathogenesis of diseases and determining the treatment. It is thought that AF causes Barre Lieou syndrome, which also includes vertebrobasilar insufficiency (VBI) findings, by compressing the structures within AF, therefore foramen decompression is performed in its treatment $(19,20)$. However, only one study was found in the literature in English (18).

In this study, we investigated the incidence of AF and the effect of this foramen on VA in colored silicon injected cadavers.

\section{Methods}

Between August 2018 and February 2019, 20 sides of 10 randomly selected cadavers (50-80 years, 8 males, 2 females) who were injected color silicone in University of Wisconsin Neuroanatomy Laboratory were incised with a reverse $\mathrm{U}$-shaped incision applied behind the ear in prone position. Muscles in the craniovertebral junction were dissected, and occipital region and upper cervical vertebrae up to C3 were revealed. OPMI Neuro/NC 4 surgical microscope was used for dissection. AF dimensions (D1=horizontal length of AF, D2=vertical length of AF), and pre-foraminal (a), intra-foraminal (b) and post-foraminal (c) VA

\begin{tabular}{|l|} 
Appendix 1 . Various nomenclatures used to identify arcuate \\
foramen \\
\hline Arcuate foramen \\
\hline Ponticulus posticus \\
\hline Kimmerle's anomaly/variant/deformity \\
\hline Atlas bridging \\
\hline Posterior ponticle of the atlas \\
\hline Foramen atlantoideum posterius/vertebrale \\
\hline Foramen retroarticular superior \\
\hline Foramen sagittale \\
\hline Canalis arteria vertebralis \\
\hline Pons posticus \\
\hline Posterior atlantoid foramen \\
\hline Posterior glenoid process \\
\hline Posterior glenoid spiculum \\
\hline Retroarticular canal \\
\hline Retroarticular VA ring \\
\hline Retroarticular vertebral ring \\
\hline Retrocondylar bony foramen \\
\hline Retrocondylar VA ring \\
\hline VA: vertebral artery \\
\hline
\end{tabular}

diameters were measured in all cases (Figure 1A, 1B). Measurements were made with digital caliper. Descriptive statistical methods were used in the study. Data were saved to Microsoft Excel and mean values were calculated.

Since our study was conducted on cadavers, ethics committee approval was not obtained and the privacy of the cases was preserved in the pictures.

\section{Results}

AF variation was found in three of 10 cadavers examined and this variation was complete in all cases (Figure 2). All three patients were male, and AF was unilateral on the right side in two patients and bilateral in one patient (Tables 1, 2). The mean pre-foraminal, intra-foraminal and
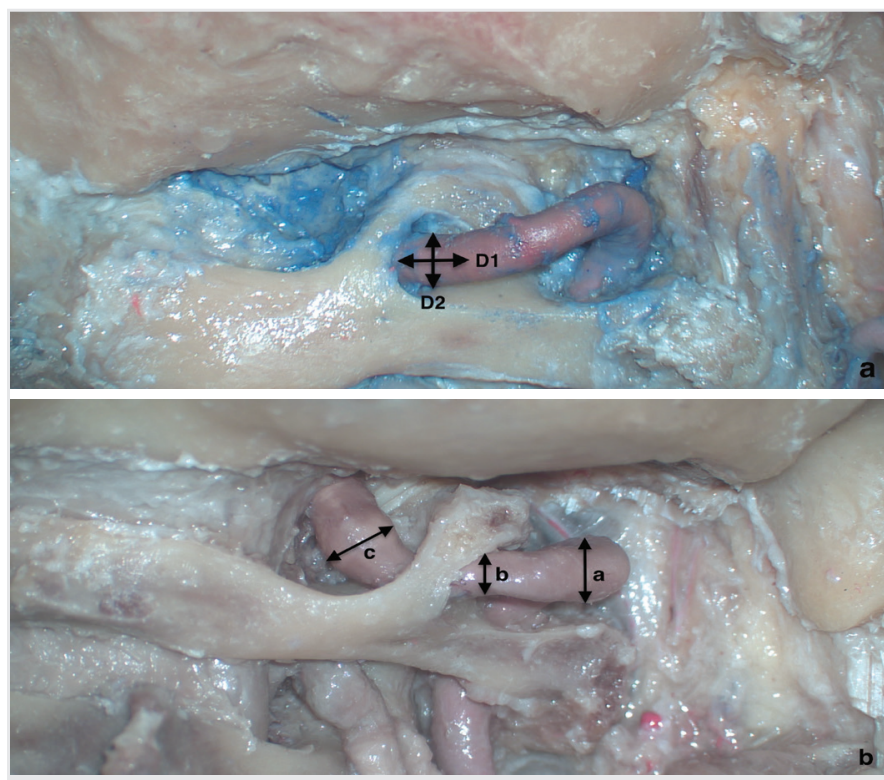

Figure 1. A) Arcuate foramen dimensions, D1=Horizontal length, D2=Vertical length. B) a: pre-foraminal, b: foraminal, c: post-foraminal parts of the sulcal vertebral artery

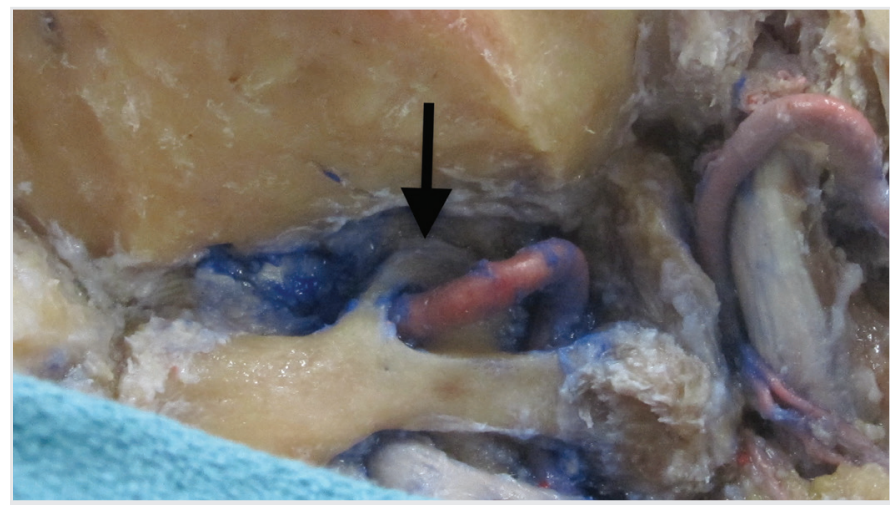

Figure 2. Complete arcuate foramen variation in the right atlas (arrow)

Table 1. Demographic characteristics of arcuate foramen

\begin{tabular}{|l|l|l|}
\hline & Case number & AF number \\
\hline Male & 3 & 4 \\
\hline Female & 0 & 0 \\
\hline AF: arcuate foramen & &
\end{tabular}


post-foraminal V3 diameters were $4 \mathrm{~mm}, 2.5 \mathrm{~mm}, 3 \mathrm{~mm}$ on the right, respectively, and $6 \mathrm{~mm}, 4 \mathrm{~mm}, 5 \mathrm{~mm}$ on the left, respectively. The mean dimensions of AF were D1 $=6 \mathrm{~mm}$ and $\mathrm{D} 2=5.5 \mathrm{~mm}$ on the right, and $\mathrm{D} 1=7.5 \mathrm{~mm}$ and $\mathrm{D} 2=6.5 \mathrm{~mm}$ on the left (Tables 3, 4). Left AF dimensions were approximately $1-1.5 \mathrm{~mm}$ wider than the right. Although AF dimensions were wider than the pre-foraminal VA, it was noted that the diameter of the V3 was narrowed at the AF level and widened again starting from the AF exit (Figure 3). In all cases, the VA was accompanied by suboccipital nerve inside the AF (Figure 4).

\section{Discussion}

In our study, we found that there was 30\% AF variation in the atlas, which is six times the incidence of AF in cadavers reported by Tubbs et al. (18). In addition, this variation was four times higher in males than in females, although there were studies reporting no statistically significant difference between the genders (Tables 1, 2) (7). Again, unlike Elliott and Tanweer's (7) meta-analyzes, AF was complete in all cases. This may be due to ethnic differences of the cases or the fact that most of the other studies were performed on dry atlas or by radiological examination. As a matter of fact, it has been reported that there are various types of $\mathrm{AF}$ variation, that its prevalence varies according to regional and ethnic groups, and that it is seen most frequently in the Middle East and North America, at least in Indians, and can be overlooked in radiological examination $(1,2,8,13,17,21)$. In our study, the high incidence of AF may be related to the fact that we conducted this study in North America.

\begin{tabular}{|l|l|}
\hline Table 2. Characteristics of arcuate foramen \\
\hline Case number & 3 \\
\hline Bilateral & 1 \\
\hline Unilateral & 2 \\
\hline Only on the right & 2 \\
\hline Only on the right & $(-)$ \\
\hline Complete & 4 \\
\hline Incomplete & $(-)$ \\
\hline
\end{tabular}

\begin{tabular}{|c|c|}
\hline Dimensions & Mean \\
\hline \multicolumn{2}{|l|}{ Length } \\
\hline Right & $6 \mathrm{~mm}$ \\
\hline Left & $7.5 \mathrm{~mm}$ \\
\hline \multicolumn{2}{|l|}{ Height } \\
\hline Right & $5.5 \mathrm{~mm}$ \\
\hline Left & $6.5 \mathrm{~mm}$ \\
\hline
\end{tabular}

Table 4. Mean diameter of V3 in the sulcal piece of vertebral artery in cadavers

\begin{tabular}{|l|l|l|l|}
\hline Diameter & Pre-foraminal & Foraminal & Post-foraminal \\
\hline Right & $4 \mathrm{~mm}$ & $2.5 \mathrm{~mm}$ & $3 \mathrm{~mm}$ \\
\hline Left & $6 \mathrm{~mm}$ & $4 \mathrm{~mm}$ & $5 \mathrm{~mm}$ \\
\hline
\end{tabular}

It has been reported that the only advantage of this variation is the low risk of fracture, and it has also been reported that it usually leads to dissection by stretching the VA, vertebrobasilar ischemia during strong interventions in the cervical spine, complications in cases where C1-C2 stabilization is required, and Barre Lieou syndrome mostly by causing neurovascular compression $(1,5,7,14,15,18,19,22-27)$.

Anatomical studies in stained cadavers are important not only because of demonstrating the variation itself, but also the relationship between neighboring vascular and neural structures. In this way, it can be easier to understand the etiology of the pathology due to variation and to find solutions against this pathology.

In the literature, the portion of VA between C2 and foramen magnum is called the third segment (V3) and left VA is reported to be generally wider than the right $(3,28)$. In our cases, the left VA was wider than the right (Table 4). In addition, although the dimensions of AF on both sides were larger than the pre-foraminal diameter of VA, V3 compression was observed at the foramen level (Table 3). Tubbs et al. (18) also reported compression of VA, however, Afsharpour et al. (29) reported that there was no compression of VA at the level of AF. This different result in the second study may be related to the fact that the AF variation in the cases is bilateral (lateral and dorsal) on both sides (29).

Not only V3, but also vertebral venous plexus, perivascular sympathetic plexus and suboccipital nerve pass through the AF located on the

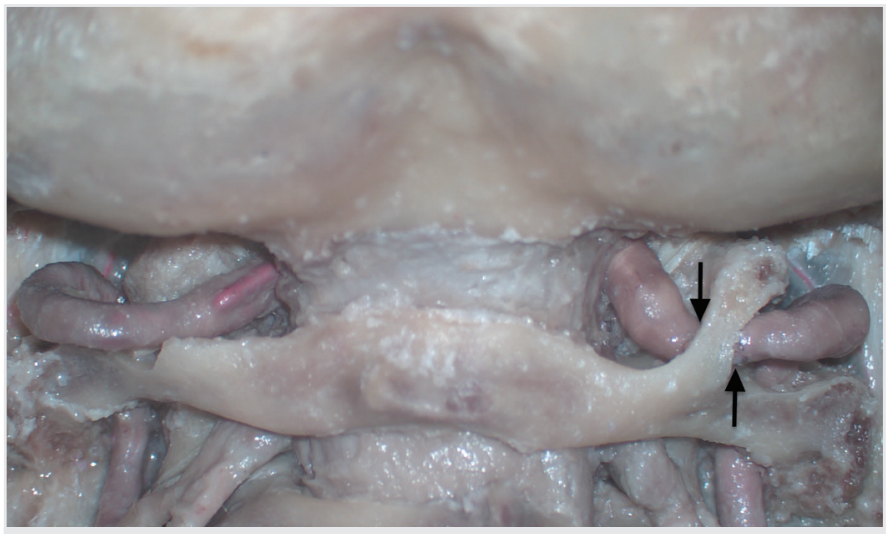

Figure 3. Unilateral arcuate foramen, vertebral artery narrowing at the foramen level (arrow)

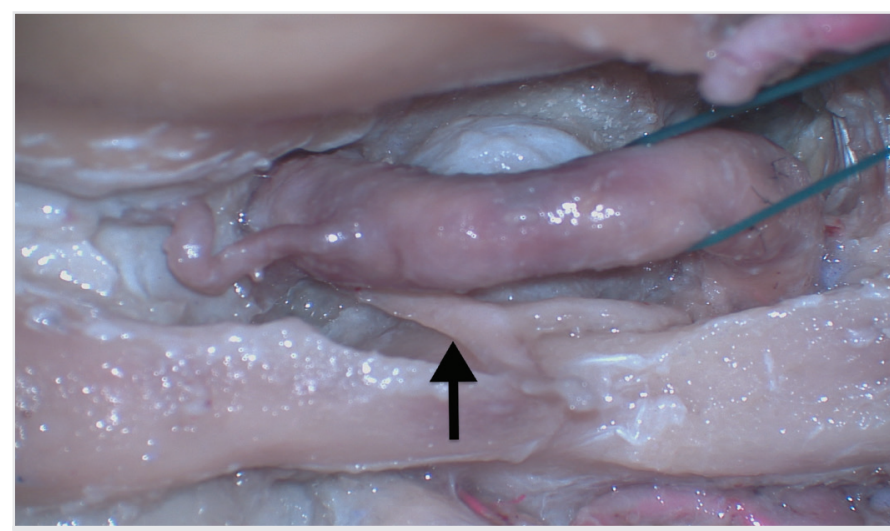

Figure 4. Suboccipital nerve in the arterial groove of the atlas (arrow) 
sulcal part of the atlas $(1,2)$. The fact that AF contains all these other neurovascular structures causes pressure on VA within the foramen. As a matter of fact, $A F$ decompression is applied in these cases considering that VBI Clinic in Barre Lieou syndrome is formed by this mechanism $(19,20)$. However, although clinical improvement was achieved in most of the cases with foramen decompression, $13.33 \%$ of young patients without cervical arthrosis also reported not to respond completely to treatment (19).

In order to fully understand the incidence of AF variation and the ethiopathogenesis of Barre Lieou syndrome, more detailed studies on cadavers of different ethnic backgrounds in different geographical regions are required. In the first stage of cadaver studies, it is difficult to obtain a large series of cases. The publication of these studies may lead to the acquisition of large series over time.

\section{Conclusion}

In our study, we encountered $30 \% \mathrm{AF}$ variation in cadavers. The high incidence of $\mathrm{AF}$ variation in the interventions to the craniovertebral junction should be remembered and a detailed examination of this region should be performed before the intervention. Thus, by determining the treatment strategy, the possibility of life-threatening VA injury can be reduced. In our study, we also found that AF dimensions are suitable for the passage of VA easily, but that the suboccipital nerve passes through this foramen and may cause arterial compression. Although this finding suggests that foramen decompression is required in the treatment of Barre Lieou syndrome, further cadaver studies are needed to elucidate the ethiopathogenesis of patients who do not respond to this treatment.

Ethics Committee Approval: Since our study was conducted on cadavers, ethics committee approval was not obtained and the privacy of the cases was preserved in the pictures.

Informed Consent: Informed verbal and written informed consent was obtained from the teachers.

Peer-review: Externally peer-reviewed.

Author Contributions: Surgical and Medical Practices - N.K.; Concept - N.K., M.B.; Design - N.K., U.Ç., B.Ö., M.B.; Data Collection and/or Processing - N.K., U.C.., B.Ö.; Analysis and/or Interpretation - N.K., U.Ç., B.Ö., M.B.; Literature Search - N.K., U.Ç., B.Ö.; Writing Manuscript - N.K., M.B.

Conflict of Interest: No conflict of interest was declared by the authors.

Financial Disclosure: The authors declared that this study received no financial support.

\section{References}

1. Ahn J, Duran M, Syldort S, Rizvi A, D’Antoni AV, Johal J, et al. Arcuate Foramen: Anatomy, Embryology, Nomenclature, Pathology, and Surgical Considerations. World Neurosurg 2018; 118: 197-202.

2. Cossu G, Terrier LM, Destrieux C, Velut S, François P, Zemmoura I, et al. Arcuate foramen: "Anatomical variation shape or adaptation legacy?" Surg Radiol Anat 2019 Jan 17.
3. Cakmak O, Gurdal E, Ekinci G, Yildiz E, Cavdar S. Arcuate foramen and its clinical significance. Saudi Med J 2005;26:1409-13.

4. Cirpan S, Yonguc GN, Edizer M, Mas NG, Magden AO. Foramen arcuale: a rare morphological variation located in atlas vertebrae. Surg Radiol Anat 2017; 39 : 877-84.

5. Cushing KE, Ramesh V, Gardner-Medwin D, Todd NV, Gholkar A, Baxter P, et al. Tethering of the vertebral artery in the congenital arcuate foramen of the atlas vertebra: a possible cause of vertebral artery dissection in children. Dev Med Child Neurol 2001; 43: 491-6.

6. Elgafy H, Pompo F, Vela R, Elsamaloty HM. Ipsilateral arcuate foramen and high-riding vertebral artery: implication on C1-C2 instrumentation. Spine J 2014; 14: 1351-5.

7. Elliott RE, Tanweer 0 . The prevalence of the ponticulus posticus (arcuate foramen) and its importance in the Goel-Harms procedure: meta-analysis and review of the literature. World Neurosurg 2014; 82: 335-43.

8. Gibelli D, Cappella A, Cerutti E, Spagnoli L, Dolci C, Sforza C. Prevalence of ponticulus posticus in a Northern Italian orthodontic population: a lateral cephalometric study. Surg Radiol Anat 2016; 38: 309-12.

9. Karau PB, Ogengo JA, Hassanali J, Odula P. Anatomy and prevalence of atlas vertebrae bridges in a Kenyan population: An osteological study. Clin Anat 2010; 23: 649-53.

10. Kavakli A, Aydinlioglu A, Yesilyurt H, Kus I, Diyarbakirli S, Erdem S, et al. Variants and deformities of atlas vertebrae in Eastern Anatolian people. Saudi Med J 2004; 25: 322-5

11. Krishnamurthy A, Nayak SR, Khan S, Prabhu LV, Ramanathan LA, Ganesh Kumar C, et al. Arcuate foramen of atlas: incidence, phylogenetic and clinical significance. Rom J Morphol Embryol 2007; 48: 263-6.

12. Le Minor JM, Trost O. Bony ponticles of the atlas (C1) over the groove for the vertebral artery in humans and primates: polymorphism and evolutionary trends. Am J Phys Anthropol 2004; 125: 16-29.

13. Saleh A, Gruber J, Bakhsh W, Rubery PT, Mesfin A. How Common is the ponticulus posticus?: A Computed Tomography Based Analysis of 2917 Patients. Spine (Phila Pa 1976) 2018 ;43: 436-41.

14. Sanchis-Gimeno JA, Blanco-Perez E, Perez-Bermejo M, Llido S, Nalla S. Retrotransverse foramen of the atlas: prevalence and bony variations. Eur Spine J 2018; 27: 1272-77.

15. Senoglu M, Gümüşalan Y, Yüksel KZ, Uzel M, Celik M, Ozbag D. The effect of posterior bridging of $\mathrm{C}-1$ on craniovertebral junction surgery. J Neurosurg Spine 2006; 5: 50-2.

16. Simsek S, Yigitkanli K, Comert A, Acar HI, Seckin H, Er U, et al. Posterior osseous bridging of C1. J Clin Neurosci 2008; 15: 686-8.

17. Stubbs DM. The arcuate foramen. Variability in distribution related to race and sex. Spine (Phila Pa 1976). 1992; 17: 1502-4.

18. Tubbs RS, Johnson PC, Shoja MM, Loukas M, Oakes WJ. Foramen arcuale: anatomical study and review of the literature. J Neurosurg Spine 2007; 6: 31-4.

19. Limousin CA. Foramen arcuale and syndrome of Barre-Lieou. Its surgical treatment. Int Orthop 1980; 4: 19-23.

20. Lvov I, Lukianchikov V, Grin A, Sytnik A, Polunina N, Krylov V. Minimally invasive surgical treatment for Kimmerle anomaly. J Craniovertebr Junction Spine 2017; 8: 359-63.

21. Taitz C, Nathan H. Some observations on the posterior and lateral bridge of the atlas. Acta Anat (Basel) 1986; 127: 212-7.

22. Arslan D, Ozer MA, Govsa F, Kıtıs O. The ponticulus posticus as risk factor for screw insertion into the first cervical lateral mass. World Neurosurg 2018; 113 : 579-85. 
23. Foster CA, Jabbour P. Barré-Lieou syndrome and the problem of the obsolete eponym. J Laryngol Otol 2007; 121: 680-3.

24. Gross A. Traumatic basal subarachnoid hemorrhages: autopsy material analysis. Forensic Sci Int 1990; 45: 53-61.

25. Huang DG, Hao DJ, Fang XY, Zhang XL, He BR, Liu TJ. Ponticulus posticus. Spine J 2015; 15: 17-9.

26. Pekala PA, Henry BM, Phan K, Pekala JR, Taterra D, Walocha JA, et al. Presence of a foramen arcuale as a possible cause for headaches and migraine: Systematic review and meta-analysis. J Clin Neurosci 2018; 54: 113-18.
27. Tambawala SS, Karjodkar FR, Sansare K, Motghare D, Mishra I, Gaikwad S, et al. Prevalence of ponticulus posticus on lateral cephalometric radiographs, its association with cervicogenic headache and a review of literature. World Neurosurg 2017; 103: 566-75.

28. Wang S, Wang C, Liu Y, Yan M, Zhou H. Anomalous vertebral artery in craniovertebral junction with occipitalization of the atlas. Spine (Phila Pa 1976) 2009; 34: 2838-42.

29. Afsharpour S, Hoiriis KT, Fox RB, Demons S. An anatomical study of arcuate foramen and its clinical implications: a case report. Chiropr Man Therap 2016; 24: 4 . 